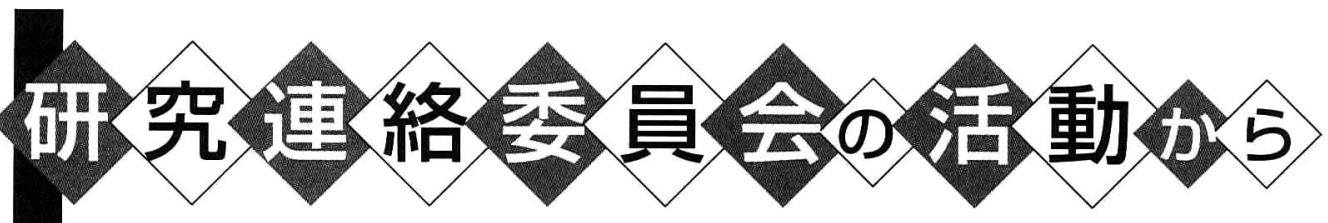

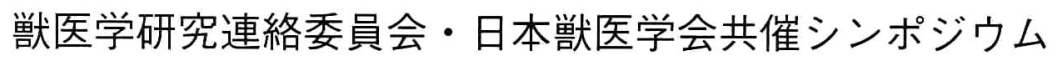

\section{日本の獣医学教育の 再構築}

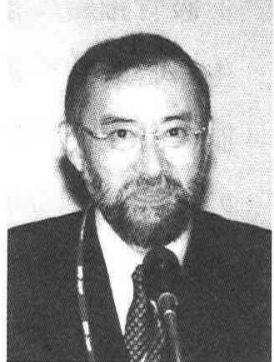

唐木 英明
わが国における獣医学教育が世界の基準にはる かに遅れている現状については、すでに本誌でも 紹介したが、獣医学研究連絡委員会は過去10年間 以上にわたって継続的に「獣医学教育の改善」を 課題に取り上げてきた。その一環として、2001年 10月7日、岩手大学において開催された第132回日 本獣医学会において、「日本の獣医学教育の再構 築」をテーマに、岩手大学内藤善久教授と獣医学 研究連絡委員会委員長唐木英明が座長を務めて、 特別教育講演シンポジウムを共催した。

\section{獣医学教育の現状と将来}

まず、「現状と将来像」と題して、唐木英明 （東京大学）が総論を述べた。すなわち、戦後、 全国に990国立大学がくまなく配置され、地域の 活性化に大きな役割を果たした。しかし、小規模 の国立大学すべてを国際レべルに整備することは 不可能であり、その域に達しない大学が多いこと も事実である。さらに、少子化と財政危機で国立 大学の基盤は弱体化している現在、大胆な再編に より国際的レベルの個性的・効率的な大学を作り 上げることは緊急の課題である。国立大学におけ
る獣医学教育は日本の国立大学の縮図と言える。 獣医学部・学科は国家試験関連18科目を教授する ことも困難な過小な組織であり、臨床や公衆衛生 の教育も十分に実施できない。

われわれは教育改善の手段として再編整備も 一つの選択と考えてきたが、大学再編の動きの 中でその動きは実現の方向に向かうものと考え る。組織のサイズとともに教育の目的、内容お よび方法についても検討し、改めてゆかなくて はならない。国立大学が充実したときには公・ 私立大学も充実しなくてはならず、これを保証 するために獣医学教育の外部評価機関の設置も 必要であろう。

\section{基䃈教育の充実}

汾陽光盛氏（北里大学）は基礎獣医学の立場 から、米国の獣医学部教官に対するアンケート 結果を踏まえて意見を述べた。米国の獣医学部 卒業生のほとんどが臨床分野に進むのに対して、 日本ではその数がおよそ半数である。さらに、 米国では獣医学部入学以前に 4 年制大学等におい て必要な基礎教育の履修が求められる点も異な 
る。進学前の基礎教育が高度な内容であるばか りでなく、入学後も半分ほどの時間を基礎教育 に費やし、カリキュラムでも基礎への配慮がな されている。「ゆとり教育」を受けてきた学生に 高度な臨床教育に耐え得る基礎学力を短時間で 教授するのは至難の技である。さらに、生命科 学研究の進展は獣医学教育にも大きく影響する であり、これらの変化に対応できる基礎獣医学 教育の充実が必要である。

\section{公衆衛生教育の充実}

杉山誠氏（岐阜大）は公衆衛生学の立場から 意見を述べた。21世紀の獣医学には、人獣共通 感染症、食品衛生、社会福祉、環境衛生という 獣医公衆衛生に関連した $4 つ の$ 分野での活動が求 められる。公衆衛生学はその対象を人においた 学問であり、動物に主体をおく動物医学とは視 点が異なるが、動物と人との関連を考えると獣 医学のすべての領域において公衆衛生学の知識 扣よび考え方が不可欠の要素であり、逆に公衆 衛生学には動物医学の基盤が必要である。

少数の教員でこのように広範な公衆衛生教育 を行うことは困難であり、現実を見ると小数の 教員しかもたない関連各大学ではその教育内容 に違いがある。十分な数の専門教員の配置と卒 後教育体制の整備が緊急の課題である。

\section{稫床教育の充実}

西村亮平氏（東京大学）は獣医臨床教育につ いて述べた。獣医学教育の中心となるべき臨床 教育の水準は、欧米諸国と比較して質的・量的 にきわめて低い。アンケート調査結果でも大学 制教育で得た知識・技術を十分とする回答は約 10\%に過ぎず、社会的要請と獣医学教育の乘離
を端的に示す。今後は教授項目の基準化、欧米 並みの診療科の専門化、clinical rotationの採用 等による問題解決能力の涵養、そして実務教育 の充実の4つをキーワードとして臨床教育の抜本 的な改善に努める必要がある。

\section{実験動物学教育}

笠井憲雪氏 (東北大学) は実験動物学教育のあり 方について述べた。生命科学研究、特に動物実験 に携わる獣医師の数は増加している。教授すべき 項目は実験動物の飼養管理、環境管理、衛生管理、 倫理、社会への啓蒙や説明等と多岐に渡り、狭義 の獣医学に留まらない間口の広い教育が必要であ る。専門的知識を備えた教員による学部教育と卒 後研修制度の確立が必要である。

\section{産業動物眳床教育}

臨床分野に職を求める卒業生の多くは小動物 臨床に従事するが、わが国に畜産業が存続する 限り、産業動物臨床獣医師を供給することは社 会的要請である。さらに、公衆衛生教育の基礎 としても産業動物臨床教育を充実することが重 要であることを述べ、内藤善久氏 (岩手大学) が 全体の締めくくりを行った。

参 考 文 献 (主として日本学術会議関係)

日本学術会議第17期獣医学研究連絡委員会報告「わが国の 獣医学教育の拔本的改革に関する提言」2000年3月27日 唐木英明、ダイアモンドは永遠に、学術の動向、2001年2 月号 48-51

唐木 英明（からき ひであき 1941年生） 日本学術会議第6部会員、獣医学研究連絡委員会委員長、 東京大学アイソトープ総合センター長、東京大学教授、農 学博士、獣医師、認定トキシコロジスト

専門：獣医学、薬理学、トキシコロジー 